\title{
From the Moral Limits of Personal Interest to the Derogation of Individual Identity: Colonialism and Oppression
}

\author{
Panos Eliopoulos \\ Doctor of Science, Associate Professor, University of Ioannina (Ioannina, Greece) \\ E-mail: eliop@uoi.gr \\ https://orcid.org/0000-0003-4966-3617
}

\begin{abstract}
In postcolonialist studies it is often neglected how the correlations between oppressor and oppressed are often more dubious than originally thought of. In our analysis it is attempted to discern limitations in moral and political action as well as the subsequent derogations for individual identity. These limitations for both sides, the oppressor and the oppressed, claim a degree of a problematic allusion of freedom and responsibility over one's own actions. For example, for Nietzsche, freedom and protection of personal interest come only as consequences of a management of resistance, as different people handle their affairs differently according to their perceptions on their identity. This notion of separation and distinct responsibilities that are assumed according to freedom interferes with our discussion on colonialism and oppression. For the German philosopher, the concept of a human subject presupposes its evolution through a historical and psychological process. Morality or moralities are revelations of the inner insights of cultures, signs and symptoms that disclose certain truths about people's or communities' ideals. But even taken in this manner, morality may be considered as a parameter of pressure for action and for assumption over a certain identity. In our paper we are mainly going to approach how this latent moral pressure on identity may be a more critical factor than initially considered as regards human action. Moral deterioration into oppression does not merely depend on parameters such as power but also on conceptualizations of power and on the surrender of sovereignty, even for lesser reasons than incapability for action. While for Nietzsche moral liberty is a matter of consciousness and is directly related with personal interest and identity, for Mill morality has to do with norms, rules, and has a canonical influence that produces utility through an altruistic approach. Contrary to Nietzsche, Mill does not comprehend how rules are dependent on other people's experiences and not on the personality of the individual even though he speaks of rational autonomy. For Mill even intention does not make a profound difference to action. In our discussion, references to Benjamin Constant and Thomas Hobbes also aim at disclosing further insights about this issue.
\end{abstract}

Keywords: Colonialism, Oppression, Identity, Personal Interest, Moral, Mill, Hobbes, Nietzsche, Constant

Received: April 12, 2019; accepted: April 24, 2019

Ukrainian Policymaker, Volume 4, 2019: 4-12.

https://doi.org/10.29202/up/4/1

(C) Eliopoulos, Panos, 2019 
In postcolonialist analyses, there is often a shift from issues of oppression, which initially are presented as political, to problems of limit in specific moral perimeters. Even more importantly, while the oppressor is accused of exceeding the limits of potential action as moral action, at the same time there is a subsequent problem of derogation for individual identity, not only for the oppressed but also for the one who exerts the oppression. These limitations for both sides claim a degree of a problematic allusion of freedom and responsibility over one's own actions. For this precise reason, Friedrich Nietzsche, in the Twilight of the Idols, clarifies that there is not only a connection between freedom and responsibility but that freedom, in fact, is the will to attain responsibility over oneself [Nietzsche, 2007: 100; cf. Nietzsche, 2005: 67]; which is also a matter of the establishment of a certain consciousness through which one perceives oneself and others. Of course, this procedure might turn to a confrontational level that at least creates distances between different readings of reality and, following, tendencies to action. Thus in the nietzschean theory, war which is a specific resort to action, is considered to be what trains people in accordance with freedom, meaning a war that will maintain the distance between oneself and the others. That poses a moral dilemma of personal identity, as through war I, as a subject, wish to differentiate between myself and another, in a relation which not only determines interest but also issues of identity, but also exerts pressure on communities or individuals to advance against one another. Nietzsche further describes a situation where people are judged according to their level of resistance to adverse condition, which is also related with issues of identity. It needs to be noted though from the beginning that freedom [Nietzsche, 2005: 92] and protection of personal interest come only as consequences of this management of resistance, as different people handle their affairs differently according to their perceptions on their identity. This notion of separation and distinct responsibilities according to freedom will interfere with our discussion on practical aspects of colonialism and oppression. For the German philosopher a moral understanding of reality is eventually more of a deception than a contact with the real world. However, the concept of a human subject presupposes its evolution through a historical and psychological process. Morality or moralities are revelations of the inner insights of cultures, signs and symptoms that disclose certain truths about people's or communities' ideals [Nietzsche, 2007: 53]. However, we would say that, even taken in this manner, morality might be considered as a parameter of pressure for action and for assumption over a certain identity. In our paper, we are mainly going to approach how this latent moral pressure on identity may be a more critical factor than initially considered as regards human action. To do that, we will use some moral notions in order to explain the nexus between personal interest and identity in relation to phenomena of oppression.

Let us start again with the case of Nietzsche. Despite his focus on distinct identity, Nietzsche discusses not so much an aristocratic code of ethics and the political power that springs from it but mostly the typical features according to which a class of people defines and affirms its existence. The gap between a morality of master and slave signifies no other than an original gap between a negation of one's own rights and the assumption that one's rights are his own to persist on. Nietzsche's theory can help us in comprehending how moral deterioration into oppression does not merely depend on parameters such as power but also on conceptualizations of power and on the surrender of sovereignty, even for lesser reasons than incapability for action. Under this prism, the affirmation of myself as a slave also means an affirmation of someone else as a master and vice versa. That is primarily a mental image of identity, far beyond interpretations of oppression in this primary stage; this mental image is practically the tendency to defy the identity of a human being who claims his participation 
in his own interest and identity. Identity, in this analysis, is not to be understood merely as a psychological continuum or under the criterion of involving necessary features or expressions within time [Schechtman, 1990: 71]; it should rather be seen in reference with terms of a moral continuity of the individual in the context of his being with others but also of being in such a form that will be recognized by him as an ever-existent even if external coherence is not present to others. In that form though, the identity issue should be referred to in terms of a dynamic change or transition towards these or other values, these or other actions. In other words, while we could be looking at identity in the manner of stable essence, we could attempt to see identity in a context of constant change and fluidity. In that context, it may be the case that no steady characteristics of individuals or nations are eventually threatened by either colonialism or oppression.

It needs to become clear that it is the access that individuals or nations have to change, their ability to make rational or irrational choices, that is put under stake or, in other words, their ability to be attached to some internal coherence of their action [Schechtman, 1990: 92]. This however, as shown above, does not necessarily come to confrontation with their mental image of themselves, which means that oppression may be starting at the place of the oppressed much before the oppressor ever comes close. Same with the oppressor: it is the mental image he maintains of himself that defines his moral choice as an oppressor. Yet, while the problem of identity is often seen as an issue directly connected with rational choice, it is precisely people's access to a wider field of choice that give oppression and colonialism a most negative tint. The important thing for identity is that intention remains in the field of the subjective. It is worth noting in relation to the above that in Sartre's existentialist outlook, the 'I' is always an existent. It has a concrete type of existence, undoubtedly different from the existence of mathematical truths, of meanings, or of spatio-temporal beings, but no less real. Based on Aristotle's thesis that the desirable is that which moves the desiring, the French philosopher insists that an acting consciousness is called to actions that come to adhere as qualities to things that call for them. The ego is the unity of states and of actions [Sartre, 2013: 49]. The ego is the creator of its states and sustains its qualities in existence by a sort of preserving spontaneity. Yet, for Nietzsche it is precisely a similar form of coherence, with some moral content in this case, that generates feelings of resentment and that, in turn, involves a reaction of those who are or have become weak that creates the reflecting and opposing image of those who are to become the masters [Nietzsche, 2005: 46-47]. There, in this conception, the loss of freedom and the gradual loss of an ideal of sovereignty have contained spermatically the creation of opposing moral characters.

So while these phenomena of colonialism or oppression may start from perceptions deeper than psychological and already inside the realm of the moral, it is interesting to observe how they can be developed or initiated. Regarding identity, it is of importance that it has to do with the subsistence of a person [Schechtman, 1990: 72], similarly of a group of persons. That means their adherence to a moral perception of themselves and others, which will lead to action and possibly to the imposition of their perception, in other words their sovereignty, over the reality that surrounds them including that of others. Since colonialism is an issue of certain sovereignty over others, it will be primarily imperative for this analysis to recall the theories of Benjamin Constant who discusses a mild form of losing access to sovereignty and to the capability for a full emergence of identity, as he poses the argument that a citizen would probably have to cherish his enjoyment of private pleasures and independence while power would deprive him of political freedom. Giving power away, in the form of sovereignty, 
guarantees the political freedom of the individual that will be necessary and tolerated within a state; that is the conclusion of Constant. Thus, a level of subordination will demand the citizen's dispossession from power, practically no other than an open exigency for oppression from someone who makes the decisions over him. The same, in some analogy, could bear validity for situations of colonialism; while there would a surrender of personal interest for those oppressed, there would emerge the liberation of the personal interest of those who are the oppressors. That asymmetry would signify a requisite transfer of power, which would be a transfer of limits, thus allowing morality to recede. In this scheme, morality would have previously been no other than the equilibrium between two unequal conditions. Now that morality has found a mean between oppressor and oppressed power becomes limitless for one of the parts and stands above this equilibrium of morality, above rules or above the potency of regression. Power cannot anymore be diminished, due to this equilibrium of moral identities; on the contrary if one of them were to recede the other would have to advance beforehand and with determination. As Constant rightly admits: "how is it possible to limit power other than through power itself?"' [Constant, 1999: 182].

The French thinker establishes a contrastive relation between arbitrariness and political freedom but also another contrastive one between arbitrariness and morality. As Constant remarks: "arbitrary power destroys morality; for there can be no morality without security... men always tend to avoid pain: when what they love is threatened, they either detach themselves from it, or defend it. Arbitrary power is for the moral what the plague is for the physical" [Constant, 1999: 290; cf. Lumowa, 2010: 399]. In such a situation, Constant seems convinced that it will not take long before private morality becomes engulfed in the wreck of the public [Constant, 1999: 66]. Hence, the French philosopher presupposes (although he seems attached to a moral conception of power), that the symptoms of oppression and subordination can be recognized quite effortlessly: "[today] the individual is lost in the multitude, he can almost never perceive the influence he exercises. Never does his will impress itself upon the whole; nothing confirms in his eyes his own cooperation" [Constant, 1999: 316]. He also tends to identify further risks, namely that the danger of liberty is that absorbed in the enjoyment of private independence and in the pursuit of individual interests the right to share in political power may be surrendered [Constant, 1999: 326]. However, is not that how always the moral orientation of such societies comes at stake?

Constant remains adamant that individual liberty is the only true liberty while he maintains that political liberty is its guarantee. Still he believes that even in these milder forms of sovereignty sacrificing individual liberty in order to guarantee political liberty, surely means that political liberty will be detached as well [Constant, 1999: 323; cf. Lumowa, 2010: 404]. While he is convinced that social responsibility will safeguard the context of a political and individual liberty, he claims that the only effective policy is loyalty and legality; obedience to the laws [Constant, 1999: 270]. Thus, Constant theoretically insists on the irreducibility of political participation while he accepts, even indirectly, that the individual's subordination should avert some of the political arbitrariness [cf. Lumowa, 2010: 399]. The only risk he sees is that individual liberty is in danger only due to the arbitrariness of power even though he allows the establishment of a power that has all the means to become arbitrary. Apart from the aforementioned slides [Holmes, 1984: 31], Constant tends to entrust to the institutions much more than he entrusts to the people themselves. That bring up reasons to uphold that perhaps Constant is more enthusiastic about the identity and the subsequent interest of institutions than that of individual. Constant tends to entrust particular moral preconditions and he misses the 
opportunity to discern how the surrender of power does not only mean the surrender of liberty but also that of personal interest and the termination of the emergence of identity.

Hobbes gives another account of moral and political reality, one closer to the ideas that Nietzsche discusses even though for him there is no schism between men but there is ample and unforced equality at the beginning of their political coexistence. Hobbes upholds that "persons naturally seek the society of others" [Stanlick, 2002: 347] although it remains important that this does not occur out of a natural tendency of likeness but for security and individual survival. While for Aristotle there is the ideal of a friend as a second self, for Hobbes the other person, or more correctly, the other "citizen", is valuable for being a necessary source that contributes to surrendering rights of sovereignty, therefore of power ${ }^{1}$. Hobbes, in this manner, sees that the moral prerequisites are not truly altered but challenged and he practically predicts the functions of colonialism as a scenario of deterioration from his original descriptions of the State. Same with issues of identity: human connection for Hobbes stresses out the temporal character of all human affairs in any other case than that of those developed as connections for reasons of mutual utility under the aegis of a sovereign authority. Hence, his system is deprived of the possibility for an identity that can be formed through and along that of others, through identities other than those of distinction. In the same spirit, in Leviathan, Hobbes brings up the "mutual help" that human beings can offer to one another although this is supposed to be a facilitation of their own wills and purposes [Molesworth, 1839-1845: 138]. The citizens in a Hobbesian universe cannot be entrusted with sharing anything that does not directly belong to the Polis and is established as their own property. Long term commitment, trust, cooperation, are farfetched goals that do not belong to the description of the human nature that Hobbes insists on. This particular pessimism ${ }^{2}$ eventually deprives Hobbes' Leviathan from a democratic conscience and again describes some form of oppression that comes from an unequal understanding of identity and interest.

Hobbes remains adamant, in De Cive, that we do not: "by nature seek society for its own sake, but that we may receive some profit or honor from it... all society is either for gain, or for glory; that is, not so much for love of our fellows, as for the love of ourselves" [Molesworth, 1839-1845: 3, 5]. That comes in conflict with Nietzsche's idea that there is absolutely no form of contract based on such feelings behind and before people's gathering. Hobbes though does not discern how any type of political friendship or recognition of personal interest would be able to conduce to the necessary stabilization of authority, a situation that Nietzsche predicts when he upholds that those who are superior will exert sovereignty and will obtain certain progress over those who are found in guilt and in a distorted image of virtue for themselves [Nietzsche, 2005: 85, 92]. In fact, Hobbes tends to criticizes Aristotle for failing to understand the true nature of the political in the form of sovereignty [Curtis, 1985: 327]. Political unity in Hobbes has to be sought through other means. As stated again in De Cive, the only feasible unity is that which is practicable after we surrender our natural rights of sovereignty to one authority [Molesworth, 1839-1845: 68] which will be from then on burdened with keeping security and prosperity for all units. In this way, Hobbes proposes a society, which is surrendered to

${ }^{1}$ Thomas Hobbes, De Cive, p. 91: "For each citizen compacting with his fellow, says thus 'I convey my right on this party, upon condition that you pass yours to the same': by which means, that right which every man had before to use his faculties to his own advantage, is now wholly translated on some certain man or council for the common benefit".

${ }^{2}$ Thomas Hobbes, De Cive, p. 75: "For all men, by a necessity of nature, choose that which to them appears to be the less evil." 
everlasting qualitative dichotomy, and Nietzsche obviously does the same but through another moral and practical perspective.

While authority makes a necessary distinction between relations that come closer to Nietzsche's theory and to subsequent perceptions of power, identity and interest, it is paramount to see how conformity affects the functions of this construction that bears clear signs of moral recognitions much before the political recognitions that it entails. To bring an example, for John Stuart Mill, conformity meddles with the possibility of true and essential freedom for the individuals. For that reason, and opposite to Hobbes and Nietzsche, in order to preserve any morality in one's identity, for Mill, freedom and its founding principle have to take quite a complicated form. This principle of freedom is so politically perplex that it even requires that one cannot be free not to be free; in other words, one cannot be allowed to alienate his freedom as part of his identity [Mill, 1983: 172]. The general thesis that the British thinker holds is that a person is generally held accountable to society only for actions that concern the interests of others and may be prejudicial to them [Mill, 1983: 158]. In times of colonialism and oppression that would mean that there is a moral burden on those who exert coercion as a necessary condition but also, quite more interestingly, a shift from collective interest to personal interest. Mill though rejects that necessity is the same thing as coercion; freedom is achievable as long as one activates those means that will bring his changes, whether in character or in life, in fruition [cf. Ryan, 1970: 104-106]. Even in the recognized necessities of his logical system Mill admits that actions and their causes should be considered as casually determined events although he confesses that this could destroy the concept of personal identity; it would be as if the agent disappears, leaving his place to a spectator of things that happen [cf. Ryan, 1970: 129-130]. For Mill it is significant to maintain that the individual is not dragged behind events or the will of others. Hence it is morally more than politically imperative that personal interest should not be limited unless one aims at restricting the emergence of other subjects' identities and at exploiting their access to power.

According to Skorupski, in Mill's theory, no person has a right to something if there is not a parallel obligation in society to either protect that person while he acquires that thing or to guarantee the resources which will enable him for that acquisition. Therefore rights of justice, in the philosophy of the British scholar, are analogous to particular obligations of society; something that stands far from Nietzsche's conception on efforts of conformity. Claiming on justice signifies that one claims on other human beings to join in making safe the prerequisites of one's personal existence and that, of course, in turn is reciprocated, to those who join, by each one's individual contribution to common safety [Skorupski, 1989: 18; cf. Ryan, 1970: 213-230]. By all means, one may also claim from someone else something as a right according to such justice [Mill, 1915: 80]. This seems to be an eventuation of justice as a political virtue, in a way that supersedes the moral level that is required beforehand. But in this form it presupposes a larger percentage of conformity. Yet, Mill defends individual liberties by appeal to the general good, in the utilitarian sense, while he does not make an unobstructed transition from justice to liberty for the reason that he fails to acknowledge that in real life individuals are not symmetrically placed and some have an advantage over others. Those who have the advantage may be able to maneuver into positions of power and manipulate or oppress the others. Apart from this particular focus on manipulation, there is another real danger that in accordance with the utilitarian approach sacrificing a person's interests in favor of the general good could always be justified, one way or the other. Therefore, even in this manner, a person practically would need to remain conformed to something bigger than the law [Mill, 1915: 
69-71], which is the general interest and is a latent parameter in the discussion about justice as regards the more undefined personal interest, which surprisingly though seems to be the cornerstone of liberty.

Even regarding the role of government, Mill insists that: "government altogether being only a means, the eligibility of the means must depend on their adaptation to the end" [Mill, 1991: 26]. This affirmation indicates that the means ought to be flexible to the extent where the will of the people will be deciding upon the ends. It also shows how John Stuart Mill is aware of the fact that the presence of absolute power would denote the existence of a mentally passive people. Passivity would not be useful to the State even though conformity, by many, would be received well, especially by those who rule [Mill, 1991: 56-57]. Again, passivity would create a gap between a morality of those who can serve their personal interest from positions of power and those who cannot; the practical consequences would remain the same. Still passivity may allow order on the one hand, but not progress on the other, which is also an indispensable element in Mill's reasoning. That is why; the peak of conformity for Mill comprises not only the peak of despotism but also evidence for a relentless political and moral determinism: "a good despotism means a government in which, so far as depends on the despot, there is no positive oppression by officers of state, but in which all the collective interests of the people are managed for them, all the thinking that has relation to collective interests done for them, and in which their minds are formed by, and consenting to, this abdication of their own energies. Leaving things to the government, like leaving them to Providence, is synonymous with caring nothing about them, and accepting their results, when disagreeable, as visitations of Nature" [Mill, 1991: 59].

Quite lucidly, in Mill's theory, the idea of justice and avoidance of oppression begins as conformity to law. Nevertheless, in continuation, people become aware that the law can be either good or bad and that eventually the idea of justice needs to be "that of conformity to laws which ought to exist" [Skorupski, 1989: 326]. To avoid despotism and violations, Mill exhorts that the mandates that are dictated by the law should not be obeyed unconditionally nor should they be issued in the deliberate form of laws [Mill, 1991: 28-29]. In the same context, he upholds that the administration of justice yields in importance in comparison to the human qualities that are required, and rules cannot bear the burden of giving justice without the participation of human virtues, which safeguard these rules [Mill, 1991: 38]. It follows that good government is impossible if each individual regards solely his own interests, which are selfish, and does not concern himself with the issues of general interest [Mill, 1991: 39]. To prevent such a contingency, Mill proposes that government's necessary care is to promote the virtue and intelligence of the citizens. The philosopher from London encourages a political system of participation where there is space for individual development and in this way manages to sustain a form of political community where conformity will not intrude in every facet of individual life. Thus, he avoids, at least on a theoretical level, the equilibrium of moralities that Nietzsche seems to be led to. However, that, in our point of view, creates no other than a vicious circle, where the uneven participations in power will be corrected by moral expectations. However, if I limit myself first, in the perimeter of my moral expectation, then I allow others to do that later also; accusing them will not solve the problem of my moral limitation. While for Nietzsche, moral liberty is a matter of consciousness and is directly related with personal interest and identity, for Mill morality has to do with norms, rules, and has a canonical influence that produces utility through an altruistic approach. Contrary to Nietzsche, Mill does not comprehend how rules are dependent on other people's experiences 
and not on the personality of the individual even though he speaks of rational autonomy. For Mill even intention does not make a profound difference to action [Mill, 1915: 219].

For that reason, to explain the most profound dimensions of colonialism and oppression one should carefully consider what Nietzsche believes about power and communities and return to the discrepancy that moral identities may create. In the Genealogy of Morals, he claims that as far as the power of a certain community increases, this group of people does not consider anymore the misdeeds of its individuals [Nietzsche, 2005: 79-80]. The increase in power means a subsequent enhancement of self-consciousness that defends the community or the individuals from the law. Instead of being a danger, a man who exerts his power, not just over but literally against others, will be thus regarded not as threat but as a creditor of justice. Same with colonialism: a peculiar form of justice that explains how oppressed communities are not found in a state of absence of justice but a state where justice as known in certain ideology has been overcome. In addition, this may explain how such communities are found in a condition of innocence regarding the lack of knowledge of the instincts of life; for Nietzsche this manifests how such communities eventually are faced with guilt. Of course more is involved in these arguments, primarily that there is an ideology of victory but victory does not simply mean that 'I' will ascend to a level of an authentic human being but also that others will be defeated, other people's lives will be subdued. Therefore, other people's perception of their identity is also critical in the understanding of myself. The fact remains that their morality will otherwise (unless put on an equal and uncompromising level) have to recede so that $m y$ moral code, according to $m y$ perception of identity and to $m y$ personal interest, will have also to prevail, in $m y$ recognition of superiority. Therefore, it is not the abolition of difference or distance between moralities that will conclude with the extinction of phenomena of oppression such as in colonialism; quite the contrary, an unyielding image of myself will have to coincide with a complete perception of myself as related to power, self determination and personal interest.

\section{References}

Constant, Benjamin. Political Writings. Translated and edited by Biancamaria Fontana. Cambridge University Press, Cambridge, 1999.

Johnson, Curtis. The Hobbesian Conception of Sovereignty and Aristotle's Politics. Journal of the History of Ideas, Vol. 46, No. 3, 1985: 327-347.

Holmes, Stephen. Benjamin Constant and the Making of Modern Liberalism. Yale University Press, New Haven, 1984.

Lumowa, Valentino. Benjamin Constant on Modern Freedoms: Political Liberty and the Role of a Representative System. Ethical Perspectives, Vol. 17, No. 3, 2010: 389- 414.

Mill, John Stuart. Considerations on Representative Government. Prometheus, New York, 1991.

Mill, John Stuart. Utilitarianism. Translated in Greek by Ioannis Zervos. Georgios Fexis Publishing, Athens, 1915.

Mill, John Stuart. On Liberty. Translated in Greek by Nicos Balis. Epicuros Publishing, Athens 1983.

Molesworth, William. (ed.). The English Works of Thomas Hobbes. John Bohn, London, 18391845.

Nietzsche, Friedrich. Twilight of the Idols. Translated in Greek by Theodora Semertzian. Ekdotiki Thessalonikis, Thessaloniki, 2007. 
Nietzsche, Friedrich. Zur Genealogie der Moral. Translated in Greek by Zisis Sarikas. Nisides, Athens, 2005.

Ryan, Alan. The Philosophy of John Stuart Mill. MacMillan, London 1970, pp. 104-106.

Sartre, Jean-Paul. La Transcendance de l'Ego. Esquisse d'une description phénoménologique. Translated in Greek by Alexis Ziras. Armos, Athens, 2013.

Schechtman, Marya. Personhood and Personal Identity. The Journal of Philosophy, Vol. 87, No. 2, 1990: 71-92.

Skorupski, John. John Stuart Mill. Routledge, London and New York, 1989.

Stanlick, Nancy A. Hobbesian Friendship: Valuing Others for Oneself. Journal of Social Philosophy, Vol. 33, No 3, 2002: 345-359. 